\title{
Ефективність лапароскопічного та традиційного методів хірургічної корекції пахвинних гриж у х.лопчиків за даними транскутанної оксиметрії
}

\author{
V. P. ZAKHARKO \\ Danylo Halytskyi Lviv National Medical University
}

\section{EFFECTIVENESS OF LAPAROSCOPIC AND TRADITIONAL METHODS OF SURGICAL CORRECTION OF INGUINAL HERNIAS IN BOYS ACCORDING TO TRANSCUTANEOUS OXYMETRY}

\begin{abstract}
Проведено аналіз результатів післяопераційної реабілітації 98 хлопчиків із пахвинними грижами (віком від 1 місяця до 12 років), прооперованих за традиційною або лапароскопічною методиками. Усіх хворих розподілено на 2 групи, залежно від методу операційного втручання. Хворим 1 групи $(\mathrm{N}=30$, середній вік $(1,5 \pm 0,15)$ року) проводили лапароскопічне втручання за методикою PIRS. У 2 групі $(\mathrm{N}=68$, середній вік $(4,5 \pm 0,32)$ року) виконували операційне втручання традиційним методом за методикою Дюамеля. У пацієнтів досліджували тканинну перфузію та оксигенацію паренхіми яєчка шляхом транскутанної оксиметрії до операції, на 7, 14, 30 доби та через 6 місяців після її проведення. При використанні лапароскопічного операційного втручання у хлопчиків із пахвинними грижами всіх трьох вікових груп, на відміну від традиційного методу герніотомії, спостерігається незначне зниження рівня оксигенації тканин яєчка у найближчий період після операції (14 доба) з його суттєвим поліпшенням на 30 добу і через 6 місяців. Через 6 місяців показник тканинної оксигенації в яєчку при лапароскопічному методі став кращим, ніж до операції, що пояснюється усуненням негативного впливу пахвинної грижі на елементи сім'яного канатика та більш щадною технікою операційного втручання. Традиційний метод операційного втручання, враховуючи його травматичність, супроводжується достовірним зниженням оксигенації паренхіми яєчка впродовж не менше 1 місяця після операції в усіх вікових групах. Відновлення початкового рівня оксигенації має місце в середньому лише через шість місяців спостереження. Лапароскопічний метод операційного втручання більш органозберігаючий, порівняно з традиційним, в усіх вікових групах хлопчиків із пахвинними грижами.
\end{abstract}

The analysis of the results of postoperative rehabilitation of 98 boys with inguinal hernias (aged from 1 month to 12 years) operated on traditional or laparoscopy techniques was made. All the patients were divided into 2 groups according to operative method. Patients of the 1 st group $(\mathrm{N}=30$, mean age of $1.5 \pm 0.15$ years) underwent laparoscopic intervention according to the method of PIRS. In group $2(\mathrm{~N}=68$, mean age of $4.5 \pm 0.32$ ) we performed surgical intervention by the traditional Duhamel method. In patients there was investigated tissue perfusion and oxygenation of the parenchyma of the testis by transcutaneous oxymetry before the operation and on the $7^{\text {th }}, 14^{\text {th }}, 30^{\text {th }}$ days and in 6 months after its implementation. With the use of laparoscopic surgery in boys with inguinal hernias of all three age groups, in contrast to the traditional method of herniotomy, there was a slight decrease in the level of tissue oxygenation of the testis in the immediate period after surgery $\left(14^{\text {th }}\right.$ day) with its significant improvement on the $30^{\text {th }}$ das and in 6 months. After 6 months, an indicator of tissue oxygenation in the testicle when laparoscopic method was better than before surgery, due to the elimination of the negative effect of inguinal hernia on the elements of the spermatic cord and more safely technique of surgical intervention. The traditional method of surgical intervention, given its invasiveness, accompanied by a significant reduction in oxygenation of the parenchyma of the testis for at least 1 month after surgery in all age groups. Restoring the initial level of oxygenation is observed on average only in six months of observation. Laparoscopic method of surgical intervention is more organsaving, compared to traditional, in all age groups of boys with inguinal hernias.

Постановка проблеми і аналіз останніх досліджень та публікацій. Пахвинні грижі становлять 92-95 \% серед усіх видів гриж у дітей, а операційні втручання на пахвинному каналі займають більше 33 \% у переліку планових операційних втручань [1, 2]. В дитячій хірургії використовують два способи операційного лікування пахвинних гриж у дітей: традиційну герніотомію та лапарос- копічну герніопластику $[3,4,5]$. Триває постійна дискусія щодо вибору оптимального операційного методу лікування на основі різних критеріїв у вітчизняній та зарубіжній літературі. Як відомо, стан майбутнього репродуктивного здоров'я хлопчиків із пахвинними грижами залежить від своєчасного та якісно проведеного операційного втручання, обраної методики лікування, реабі- 
літаційних заходів у післяопераційному періоді. Однак кількість спостережень не $є$ достатньою, а критерії порівняння не завжди об’єктивні, що стало метою та поштовхом до порівняльного аналізу ефективності обох способів операційного лікування пахвинних гриж у хлопчиків.

Відомо, що традиційна герніотомія не виключає можливості пошкодження елементів сім'яного канатика та сім'явиносної протоки, порушення лімфодренажної функції яєчка. Навіть ідеально виконана відкрита герніотомія приводить до травматичного спазму судин сім'яного канатика ішемії - патологічних змін у гермінативному епітелії яєчка та над’яєчка $[1,2,6]$. Водночас лапароскопічна методика дозволяє уникнути більшості з описаних вище ускладнень $[3,4,5]$.

Мета роботи: вивчити динаміку параметрів кровотоку та оксигенації яєчок, за даними транскутанної оксиметрії, в післяопераційному періоді залежно від способу операційного втручання при пахових грижах у хлопчиків.

Матеріали і методи. Проведено аналіз результатів післяопераційної реабілітації 98 хлопчиків із пахвинними грижами, прооперованих за традиційною або лапароскопічною методиками в II хірургічному відділі Комунальної міської дитячої клінічної лікарні м. Львова в період 20132016 рр. Вік дітей - від 1 місяця до 12 років. Усіх хворих розподілено на 2 групи залежно від методу операційного втручання. Хворим 1 групи $(\mathrm{N}=30$, середній вік $(1,5 \pm 0,15)$ року) проводили лапароскопічне втручання за методикою PIRS. У 2 групі (N=68, середній вік $(4,5 \pm 0,32)$ року) виконували операційне втручання традиційним методом за методикою Дюамеля. Усіх пацієнтів обстежено за методом транскутанної оксиметрії, яку проводили за допомогою апарата TCO2M 860 Respironics, Inc. 06492 (виробництво США) до операції, на 7, 14, 30 доби та через 6 місяців після її проведення. Досліджували тканинну перфузію та оксигенацію паренхіми яєчка на початку і в динаміці післяопе- раційного спостереження залежно від типу проведеного операційного втручання.

Результати досліджень та їх обговорення. Проведення лапароскопічного та традиційного методів хірургічного лікування пахвинних гриж у хлопчиків по-різному вплинуло на показники транскутанної оксиметрії, зокрема показник оксигенації паренхіми яєчка $\left(\mathrm{tcpO}_{2}\right)$. У молодшій групі хлопчиків, прооперованих лапароскопічно (I A), спостерігали поступову достовірну позитивну динаміку tсрО 2 на 30 добу $((59,33 \pm 0,45)$ мм рт. ст.) і

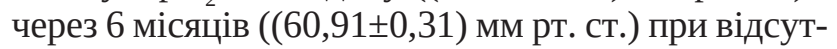
ності падіння рівня цього показника в найближ-

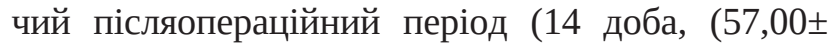
0,49) мм рт. ст.) порівняно з початком спостере-

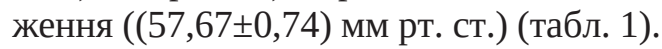

На відміну від цього, у хлопчиків молодшої групи, прооперованих традиційним методом (I Б), враховуючи його травматичність, відмічали достовірне падіння рівня середньої оксигенації на 14-30 добу спостереження (відповідно, до $(55,75 \pm 1,18)$ та $(55,75 \pm 1,1)$ мм рт. ст.; $<<0,05)$ порівняно зі стар-

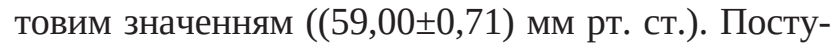
пове відновлення оксигенації в цій групі спостерігали лише через 6 місяців, але все одно не досягало вихідного рівня $((57,00 \pm 0,71)$ мм рт. ст.).

У II віковій групі дітей, прооперованих лапароскопічно (II A), спостерігали аналогічну динаміку, хоча було зареєстровано незначне падіння оксигенації на 14 добу, яке виявилось більш вираженим, ніж у I А віковій групі $((56,46 \pm 0,38)$ мм рт. ст.). У подальшому рівень цього показника у II А групі достовірно збільшився: на 30 добу він становив $(58,00 \pm 0,47)$ мм рт. ст. $(\mathrm{p}<0,05)$, через 6 місяців - $(59,86 \pm 0,306)$ мм рт. ст. ( $<0,001)$. На відміну від цього, у пацієнтів, прооперованих традиційною методикою (II Б), спостерігали більш суттєве зниження оксигенації на 14

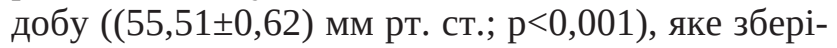
галося і на 30 добу $((56,51 \pm 0,48)$ мм рт. ст.). Відновлення рівня оксигенації до стартового рівня

Таблиця 1. Динаміка показника транскутанної оксиметрії (tсро $\mathrm{2}_{2}$ мм рт. ст.) на етапах спостереження

\begin{tabular}{||c|c|c|c|c|c||}
\hline \hline \multicolumn{2}{|c|}{ Групи пацієнтів } & До операції & 14 доба & 30 доба & 6 місяців \\
\hline \multirow{2}{*}{ I } & I A ( $\mathrm{n}=12)$ & $57,67 \pm 0,74$ & $57,00 \pm 0,49$ & $59,33 \pm 0,45^{* *}, \#$ & $60,91 \pm 0,31^{* * *}, \# \#$ \\
\cline { 2 - 6 } & I Б (n=4) & $59,00 \pm 0,71$ & $55,75 \pm 1,18 \#$ & $55,75 \pm 1,1 \#$ & $57,00 \pm 0,71$ \\
\hline \multirow{2}{*}{ II } & II A ( $=15)$ & $58,00 \pm 0,31$ & $56,46 \pm 0,38 \#$ & $58,00 \pm 0,47 *$ & $59,86 \pm 0,306^{*}, \# \# \#$ \\
\cline { 2 - 6 } & II Б (n=35) & $58,94 \pm 0,49$ & $55,51 \pm 0,62 \# \# \#$ & $56,51 \pm 0,48 \#$ & $58,45 \pm 0,38$ \\
\hline \multirow{2}{*}{ III } & III A (n=3) & $59,33 \pm 0,33$ & $57,66 \pm 0,66 \#$ & $62,33 \pm 0,66 * * *, \# \#$ & $62,1 \pm 0,01^{* *}, \#$ \\
\cline { 2 - 6 } & III Б (n=29) & $58,68 \pm 0,55$ & $55,93 \pm 0,45 \# \# \#$ & $57,65 \pm 0,41 \#$ & $58,96 \pm 0,32$ \\
\hline \hline
\end{tabular}

Примітка. * $\mathrm{p}<0,05$; ** $\mathrm{p}<0,01$; *** $\mathrm{p}<0,001$ - достовірність між підгрупами А і Б; \# p<0,05; \#\# p<0,01; \#\#\# p<0,001 - достовірність різниці в динаміці на 14 добу, 30 добу та через 6 місяців спостереження порівняно з початковим показником. 
відбулось лише через півроку, досягши середнього значення $58,45 \pm 0,38$.

У III віковій групі результати після лапароскопічного методу хірургічного втручання (III A) також виявилися більш сприятливими щодо стану відновлення оксигенації тканин яєчка. Порівняно зі стартовим показником, на 14 добу у хлопчиків III А групи спостерігали незначне післяопераційне зниження середнього показника до $(57,66 \pm 0,66)$ мм рт. ст. із суттєвим його покращенням на 30 добу $((62,33 \pm 0,66)$ мм рт. ст.; $<<0,01)$, що утримувався на високих рівнях і в подальшому - через 6 місяців $((62,10 \pm 0,01)$ мм рт. ст.; $<<0,05)$. На відміну від цього, у пацієнтів, прооперованих за традиційною методикою (III Б), спостерігали більш суттєве зниження оксигенації на 14 добу $((55,93 \pm 0,45)$ мм рт. ст.; $p<0,001)$, яке зберігалося і на 30 добу $((57,65 \pm 0,41)$ мм рт. ст.; $\mathrm{p}<0,05)$. Відновлення рівня оксигенації до стартового відбулося лише через півроку, досягши $(58,96 \pm 0,32)$ мм рт. ст. Метод транскутанної оксиметрії дозволяє неінвазивним способом встановити ступінь насичення киснем тканини. Переважно цей метод використовують у судинній хірургії $[7,8]$.

Ми застосували цей метод вперше, бо він $є$ неінвазивний і дозволяє оцінити стан перфузії тканин яєчка за показником ступеня насичення киснем. У дітей локальна перфузія дуже чутливо реагує на будь-які зовнішні впливи та вибір методу операційного втручання. У нашому дослідженні у дітей, які прооперовані за лапароскопічною методикою, особливо у молодшій віковій групі, після корекції пахвинної грижі стан тестикулярної оксигенації навіть покращився порівняно зі стартовим показником. Це можна пояснити негативним впливом пахвинної грижі на елементи сім'яного канатика та значне порушення кровотоку в яєчку. Наші дані збігаються з даними інших дослідників [1, 2]. У хворих, прооперованих традиційним методом, відновлення оксигенації яєчка

\section{СПИСОК ЛІТЕРАТУРИ}

1. Горбатюк О. М. Проблеми грижесічення з приводу пахвинної грижі у хлопчиків / О. М. Горбатюк // Клінічна хірургія. - 1999. - № 10. - С. 44-46.

2. Горбатюк О. М. Загальні закономірності патогенезу чоловічої неплідності, обумовленої патологією вагінального відростка очеревини / О. М. Горбатюк // Урологія. - 2000. - № 2. - С. 47-49. 3. Percutaneous internal ring suturing: a simple minimally invasive technique for inguinal hernia repair in children / D. Patkowski, J. Czernik, R. Chrzan [et al.] // J. Laparoendosc. Adv. Surg. Techn. - 2006. - Vol. 16. - P. 513-517.

4. Chang Y. T. Technical refinements in single-port laparoscopic surgery of inguinal hernia in infants and children / Y. T. Chang // Diagnostic and Therapeutic Endoscopy. - 2010. - Vol. 6. - P. 6 до початкового рівня відбулося тільки в III групі, а у I і II групі не досягло навіть вихідного рівня, що потребує тривалішої реабілітації із застосуванням додаткової фармакотерапії.

Висновки. 1. При використанні лапароскопічного операційного втручання у хлопчиків із пахвинними грижами всіх трьох вікових груп, на відміну від традиційного методу герніотомії, спостерігається незначне зниження рівня оксигенації тканин яєчка у найближчий період після операції - 14 доба - з його суттєвим покращенням на 30 добу і через 6 місяців. Через 6 місяців показник тканинної оксигенації в яєчку при лапароскопічному методі став кращим, ніж до операції, що пояснюється усуненням негативного впливу пахвинної грижі на елементи сім'яного канатика та більш щадною технікою операційного втручання.

2. Традиційний метод операційного втручання, враховуючи його травматичність, супроводжується достовірним зниженням оксигенації паренхіми яєчка впродовж не менше 1 місяця після операції в усіх вікових групах. Відновлення початкового рівня оксигенації спостерігається в середньому лише через шість місяців спостереження.

3. Багатофакторний аналіз показав, що лапароскопічний метод операційного втручання більш органозберігаючий, порівняно з традиційним, в усіх вікових групах хлопчиків із пахвинними грижами. Транскутанну оксиметрію $з$ визначенням $\mathrm{tcpO}_{2}$ можна рекомендувати як інформативний неінвазивний метод оцінки оксигенації паренхіми яєчка в комплексі з іншими методами, що використовуються у вивченні динаміки кровотоку і тканинної перфузії.

Перспективи подальших досліджень. Подальші дослідження будуть присвячені ефективності фармакологічних методів поліпшення результатів післяопераційної реабілітації у хлопчиків, прооперованих з приводу пахвинної грижі.

5. Minimal access surgery of pediatric inguinal hernias: A review / R. Saranga, R. Bharathi, M. Arora, V. Baskaran // Surg. Endosc. - 2008. - Vol. 22. - P. 1751-1762.

6. Testicular function after herniotomy and fertility / Z. T. Homonnai, N. Fainman, G. F. Paz, M. P. David// Andrologia. - 1980. - Vol. 12. - P. 115-120.

7. Reference value of transcutaneous oxygen measurement in diabetic patients compared with nondiabetic patients / E. Vincent, P. Hans, S. Sandra [et al.] // Journal of Vascular Surgery. - 2008. - Vol. 48. - P. 382-388.

8. Hauser C. J. Tissue salvage by mapping of skin surface transcutaneous oxygen tension index / C. J. Hauser // Arch. Surg. - 1987. - Vol. 112. - P. 1128-1130. 